\title{
Observations on Zooplankton Community of Nanak Sagar Reservoir, Uttarakhand, India
}

\author{
Sumit Kumar*, Malobica Das Trakroo, Kusumlata Goswami and Hema Tewari
}

Department of Aquatic Environment Management, College of Fisheries Science, G.B. Pant University of Agriculture and Technology, Uttarakhand - 263145, India

*Corresponding author

\begin{tabular}{|l|}
\hline Ke y w o r d s \\
$\begin{array}{l}\text { Nanak Sagar, Density, } \\
\text { Diversity, Physico- } \\
\text { chemical, Reservoir, } \\
\text { Zooplankton }\end{array}$ \\
\hline Article Info \\
\hline $\begin{array}{l}\text { Accepted: } \\
\text { 04 September } 2018 \\
\text { Available Online: } \\
\text { 10 October } 2018\end{array}$ \\
\hline
\end{tabular}

\section{A B S T R A C T}

The zooplankton density and diversity along with important physico-chemical parameters were studied on forth nightly basis from August, 2016 to March, 2017 in Nanak Sagar reservoir, Uttarakhand. Three sampling sites i.e. (A1, A2 \& A3) were selected for regular sampling of zooplankton and water. The range of physico-chemical parameters i.e. water temperature, dissolved oxygen, free $\mathrm{CO}_{2}$, transparency, $\mathrm{pH}$, conductivity, total dissolved solid, total alkalinity, nitrate and phosphate during the study period were 16.9 to $34{ }^{\circ} \mathrm{C}, 3.2$ to $9.6 \mathrm{mgL}^{-1}, 0$ to $6 \mathrm{mgL}^{-1}, 67.9$ to $194 \mathrm{~cm}, 7$ to $8.7,118$ to $336 \mu \mathrm{S} \mathrm{cm}^{-1}, 91.7$ to $156 \mathrm{mg}$ $\mathrm{L}^{-1}, 60$ to $140 \mathrm{mgL}^{-1}, 0.22$ to $0.64 \mathrm{mgL}^{-1}$ and 0.043 to $0.2 \mathrm{mgL}^{-1}$ respectively. The zooplankton mainly consisted of Rotifera, Copepoda, Cladocera, Ostracoda and Diptera. Out of 24 genera of zooplankton, 10 were from rotifera, 6 from cladocera, 5 from copepoda, 2 from ostracoda and 1 belonged to diptera group. The average density of zooplankton was 6250 individuals $\mathrm{L}^{-1}, 4125$ individuals $\mathrm{L}^{-1}$ and 4000 individuals $\mathrm{L}^{-1}$ at site $\mathrm{A} 1, \mathrm{~A} 2$ and $\mathrm{A} 3$ respectively. The diversity of zooplankton showed their own maximum and minimum abundance during a particular season. The water quality parameters of Nanak Sagar reservoir reveal that the environmental conditions are good from the fisheries point of view.

\section{Introduction}

Plankton forms an important component of fish food in aquatic environment and as such, the knowledge of their production and abundance is essential for successful management of fishery. Zooplankton occupies a central position between the autotrophs and other heterotrophs and is an important link in food of a fresh water ecosystem. The study of zooplankton community is important as it provides ways of predicting productivity and it is one of the principle links in the food chain. They have been widely used in assessment of aquatic pollution because of their sensitivity to small changes in environment and short generation time.

Zooplankton community is cosmopolitan in nature and they inhabit all freshwater habitats of the world. Zooplankton diversity and density refers to variety within the community (Jalilzadeh et al., 2008). Zooplankton plays an important role in freshwater ecosystem, as grazers that control algal and bacterial 
populations, as a food source for higher trophic levels and in the excretion of dissolved nutrients (Pourriot and Meybeck, 1995) The zooplankton communities, very sensitive to environmental modifications, are important indicators for evaluating the ecological status of the ecosystems (Magadza, 1994). Wetzel (2001) stated that zooplankton not only form an integral part of the lentic community but also contribute significantly to the biological productivity of the fresh water ecosystem. Almost all fish rely upon zooplankton for food throughout their larval phases, and a few fish still eat zooplankton in their entire lives (Madin et al., 2001). Monitoring of zooplankton communities is needed to allow us to predictively model the ecosystem (Deborah and Robert, 2009).

Zooplankton communities and analysis of zooplankton with diversity indices like Shannon-Wiener and Simpson diversity index, species richness, and evenness, structure and composition trends with total abundance of various zooplankton are essential to assess the water quality and aquatic health for proper management of reservoir (Dipankar Ghosh and Jayanta Kumar Biswas, 2014).

\section{Materials and Methods}

\section{Study area}

The study was carried out for a period of eight months from August 2016-March 2017 in Nanak Sagar reservoir, Uttarakhand. In the investigation, three different sampling stations viz. sites of the reservoir (A1, A2 \& A3) were selected according to human intervention, for regular sampling of zooplankton and water samples. Site A1 is the Baoli Sahib, it is about one and a half kilometers from Gurudwara Nanakmatta Sahib. This place is also used as Boat stand and lot of people come here daily. The second site is A2 which is known as Kati pulia which is about 0.92 kilometers from site
A1 and has a steady environment. The site has a small drainage for agriculture purpose. The third site was the Dam area which is about 1.63 kilometers from site A2 and 2.5 kilometers from site A1.

\section{Plankton collection, preservation, identification and analysis}

For qualitative and quantitative estimation, of zooplankton about 100 liters of water was filtered through plankton net from the three experimental sites, (APHA, 2012). The samples were collected fortnightly in sampling bottle of 10/20 ml capacity and were preserved in formol-alcohol solution $(5 \%$ formalin and $70 \%$ alcohol in equal parts) for quantitative and qualitative analyses. The bottles were labelled with date and sampling site.

The water samples were collected fortnightly from all the sampling sites between 9.00 to 11.0 AM for analyses of water quality parameters. Water temperature, transparency, dissolved oxygen; free $\mathrm{CO}_{2}, \mathrm{pH}$, conductivity and total dissolved solids (TDS) were measured at the sampling site. For analyses of other hydro biological parameters (total alkalinity, $\mathrm{NO}_{3}-\mathrm{N}$ and $\mathrm{PO}_{4}-\mathrm{P}$ ) water samples were brought to the laboratory.

Identification of zooplankton was done using 10x and 40x objective lenses of compound microscope (Labomed). Standard reference books viz. Edmondson (1959), Needham and Needham (1962), Pennak (1978) and Tonapi (1980) were consulted for identification of zooplankton.

For quantitative analysis of zooplankton, $1 \mathrm{ml}$ subsample was taken in Sedgwick Rafter counting cell with the help of dropper and zooplankton were counted under compound microscope. A minimum of three sub samples were counted for statistical validity. The total 
number of zooplankton in each sample was multiplied with dilution factor and results were expressed as individuals $\mathrm{L}^{-1}$ (APHA, 2012).

No. of organisms counted Number of individuals $\mathrm{L}^{-1}=$

No. of replicates taken

\section{Biodiversity of zooplankton in the reservoir}

\section{Simpsons Index of diversity (D)}

This index accounts for the species richness (the number of species) and the proportion of each species (Pi). Simpsons index gives a better idea for which species is most abundant in the environment.

Calculation of the Simpsons Index of Diversity

$\mathrm{D}=\Sigma(\mathrm{Pi})^{2}$

Number of individuals of a particular species $\mathrm{Pi}=$

Total number of individuals (organisms)

\section{Shannon-Wiener diversity index $(\mathrm{H})$}

Similar to the Simpson's index, this measurement takes into account species richness and proportion of each species. The Shannon Index is used to compare diversity between habitat samples. The ShannonWiener Index $(\mathrm{H})$ has no meaning, but it is a good indicator of change when used to compare two different habitats (communities) or one habitat (community) at different times.

Similar to the Simpson index, the first step is to calculate $\mathrm{Pi}$ for each species. This number is then multiplied by the log of the number. Formulae to calculate Shannon-Wiener diversity index.

\section{$H=-2 r^{\prime} l \ln (\mathrm{pl})$}

\section{Results and Discussion}

In this study zooplankton mainly consisted of Rotifera, Copepoda, Cladocera, Ostracoda and Diptera, Among all Rotifera was the most dominant group throughout the study.

A total of 24 species were recorded during the study period, 10 were from Rotifera, 6 from Cladocera, 5 from Copepoda, 2 from Ostracoda and 1 belonged to Diptera group. Rotifera group mainly consisted of Filinia longiseta, Keratella sp., Brachionus anguilaris, Lepadella sp., Ploesoma sp., Asplanchna sp., Ascomphora sp., Philodina $s p$., Lecane sp. and Notholca sp.. Copepoda consisted of Diaptomus sp., Cyclops sp., Mesocyclops sp., Eucyclops agilis and Parastenocaris starreti. Cladocerans comprises of Bosminopsis deitersi, Alona, Bosmina longirostris, Chydorus sp., Moina sp., Kurzia latissima.

Ostracoda consisted of Stenocypris longicomosa and Eucypris fascatus species and in Diptera Chaoborus was recorded during the study period from all the sites of the reservoir (Fig. 1-5 and Table 1).

\section{Rotifera}

Rotifers play a vital role in the trophic tiers of freshwater impoundments and serve as living capsule of nutrition (Suresh Kumar et al., 1999). In the present study they dominated with 10 species as compared to other groups of zooplankton. Taxonomic dominance has been reported in several water bodies (Neves et al., 2003; Kudari et al., 2005; Kanagasabhapati and Rajan, 2010). Segers, 2003 highlighted the dominance of rotifer population in Dekhu reservoir, Aurangabad which was due to its preference for warm waters. 


\section{Copepoda}

Freshwater copepods constitute one of the major zooplankton communities occurring in all types of water bodies. They serve as food to several fishes and play a major role in ecological pyramids. In the present study, 5 species were recorded. Abundance of copepods in summer and winter is due to high matter supporting higher number of Cyclopoids, thus suggesting their preponderance in higher trophic state of water. Similar observations were made by Somani and Pejavar (2004) in Masunda Lake.

\section{Cladocera}

Cladocerans are the most useful and nutritive group of crustaceans for higher members of fishes in the food chain. In the present study, a total of 6 species were recorded.

Abundance has also been earlier reported in monsoon season and lower in summer by Pawar and Pulle (2005) in Pethwadaj dam of Nanded district.

\section{Ostracoda}

Ostracods represented very low diversity and population density as compared to other groups of zooplankton. In the present study, 2 species of ostracods were recorded. Similar result has also been observed by Sukand and Patil (2004) in Fort Lake of Belgaum and Kedar et al., (2008) in Rishi freshwater lake of
Washim district. Martin Gross et al., (2015) documented five ostracod species and their distribution in ten similar-sized lakes and reservoirs in Bolu, Turkey.

\section{Diptera}

In the present study, 1 species of diptera was recorded which include Chaoborus. One of the most important invertebrate predators in freshwater lakes is the larva of the Dipteran Chaoborus. These larvae occur in many freshwater habitats, from temporary ponds to large lakes, all over the world. They are particularly common throughout the tropics and are often a major component of the limnetic food web in African lakes such as Lake Geinde in Uganda Lake Malawi (Irvine, 1997) Lake Chad (Saint-Jean, 1983) or small Opi Lake in Nigeria (Hare \& Carter, 1987).S

Among all the zooplankton, rotifer has maximum diversity and population density in all the seasons. The dominance of rotifers in the reservoir was due to the continuous supply of food material which in turn indicates the eutrophic nature of the lake (Sukand and Patil, 2004) and that of Sona Dighi reservoir (Naz and Najia, 2008). Average number of Copepods were noticed during monsoon and winter, but were too less in summer season. As compared to Rotifera and Copepoda, population density of Cladocera, Ostracod and Diptera was very low in all the seasons and they did not also show remarkable seasonal fluctuation.

Table.1 Diversity indices of zooplankton at different sites of Nanak Sagar reservoir

\begin{tabular}{|l|l|l|l|}
\hline Diversity Indices & Site A1 & Site A2 & Site A3 \\
\hline Shannon-Wiener index of diversity (H) & 3.14 & 3.32 & 3.12 \\
\hline $\begin{array}{l}\text { Simpson index of diversity (D) } \\
\text { D= Simpson index of diversity } \\
\text { H= Shannon-Weiner index of diversity }\end{array}$ & 0.32 & 0.30 & 0.32 \\
\hline
\end{tabular}


Fig.1 Satellite view of Nanak Sagar reservoir showing all three sites (A1, A2 and A3)

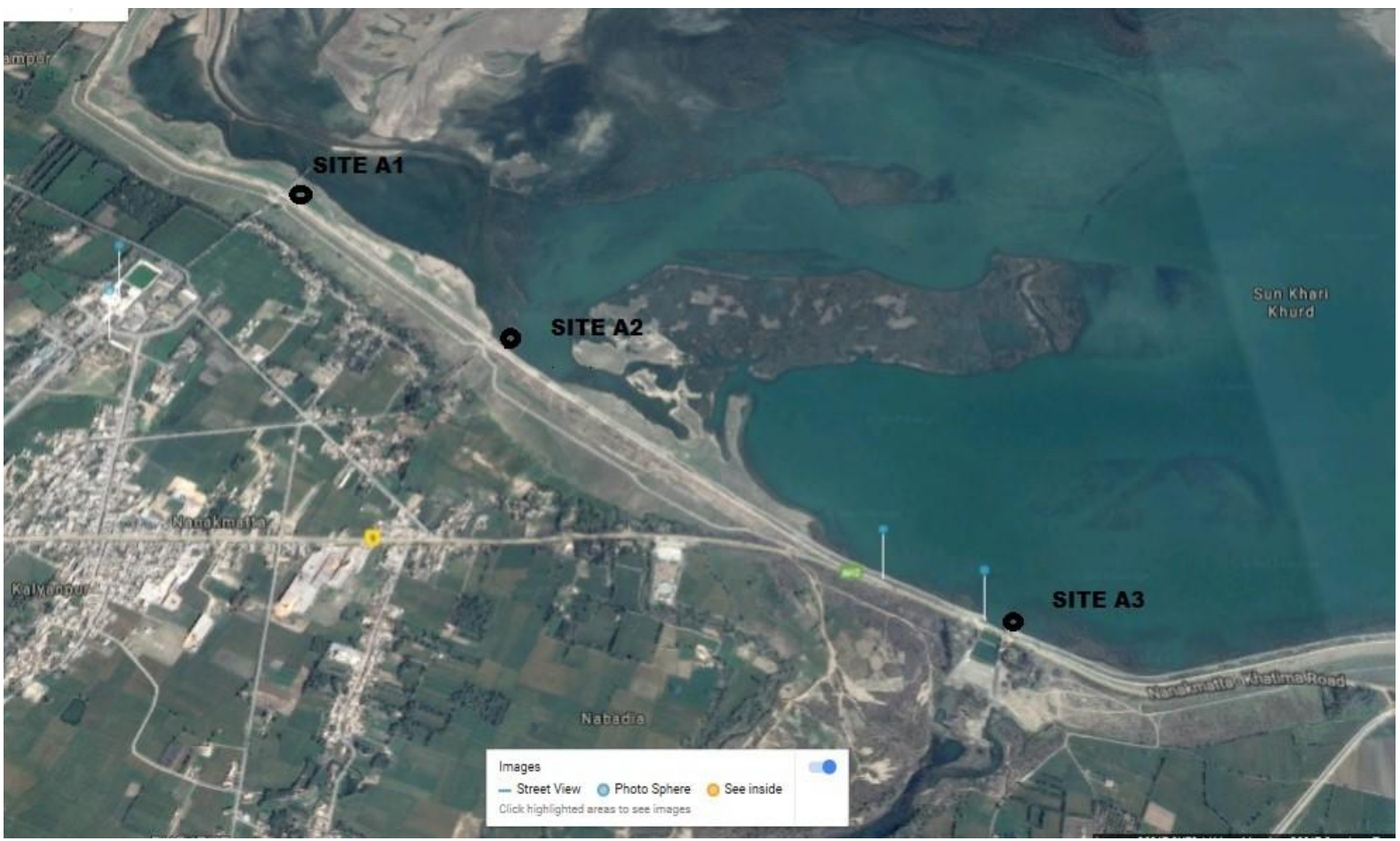

Fig.2 Monthly percent variation of zooplankton at site A1 in Nanak Sagar reservoir

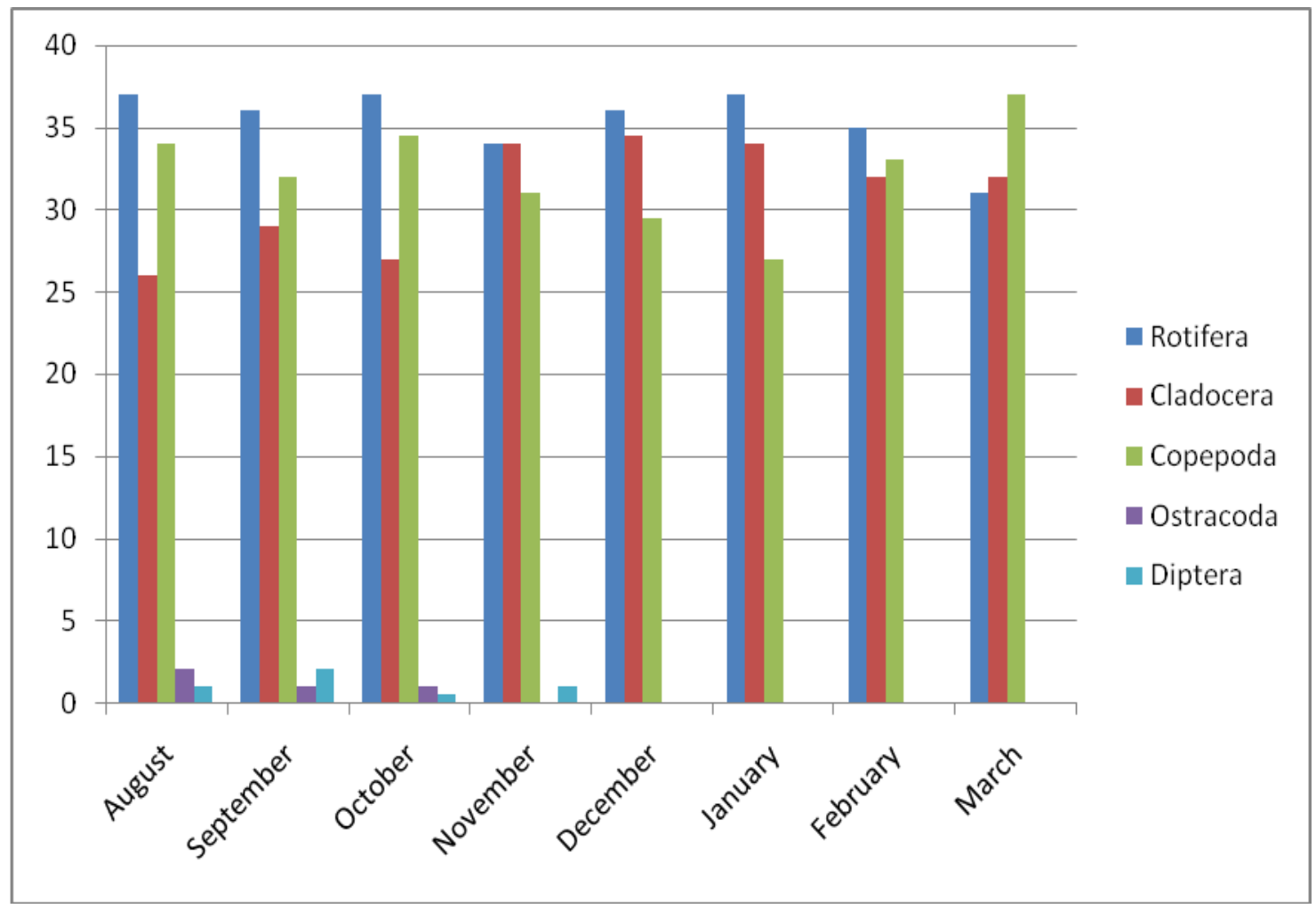


Fig.3 Monthly percent variation in of zooplankton at site A2 in Nanak Sagar reservoir

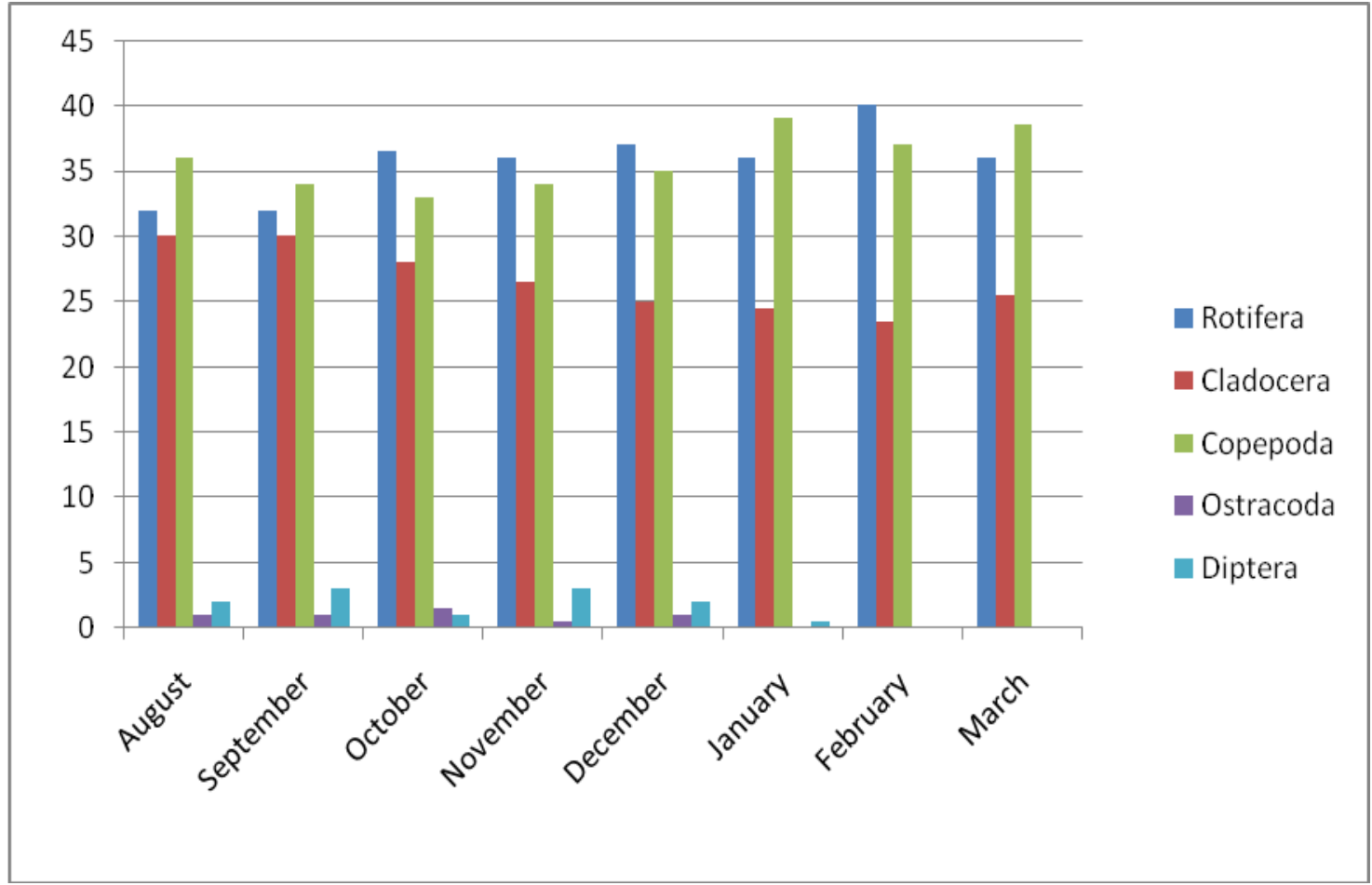

Fig.4 Monthly percent variation in of zooplankton at site A3 in Nanak Sagar reservoir

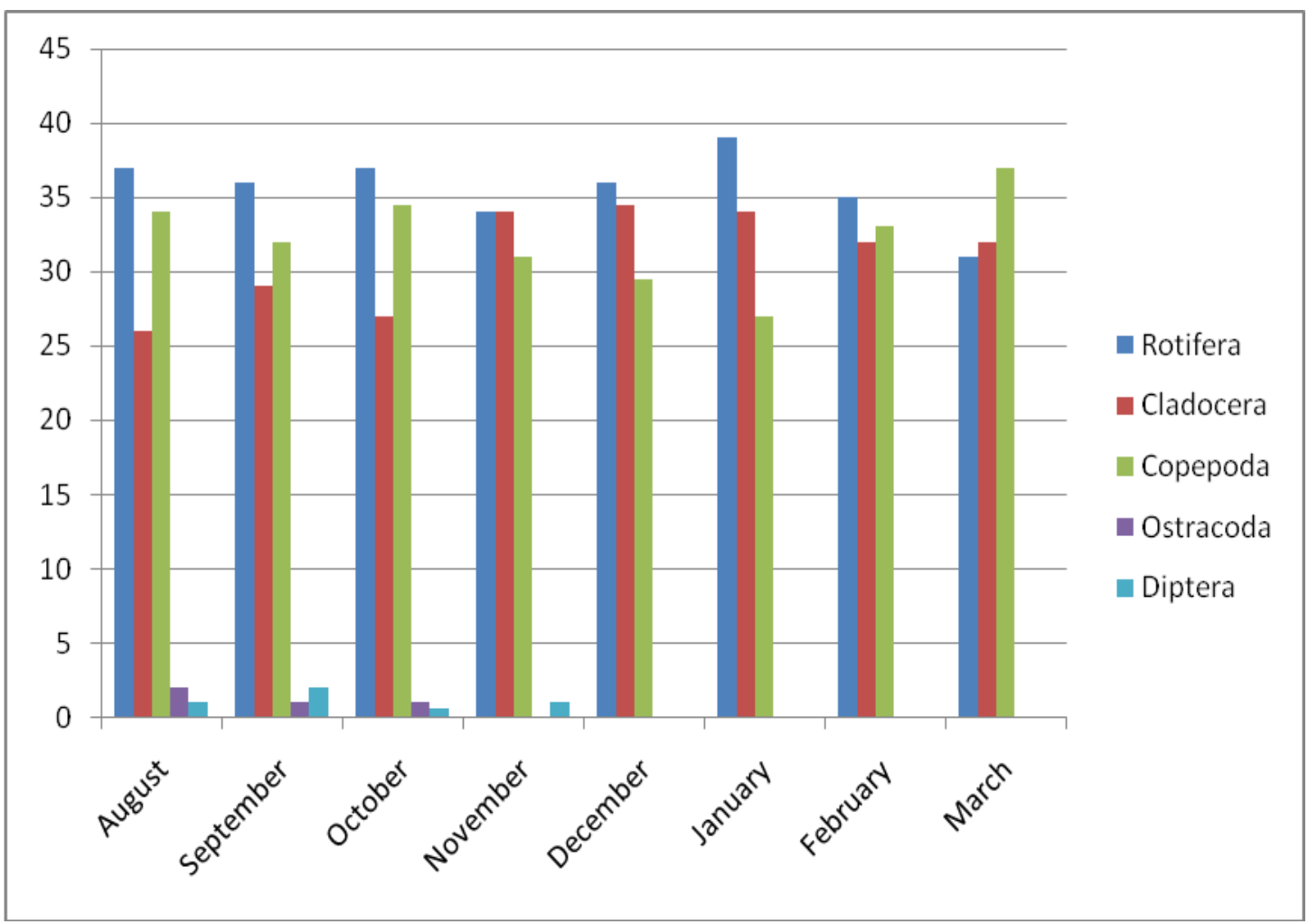


Fig.5 Average zooplankton individual $\mathrm{L}^{-1}$ at site A1, A2 and A3 of the Nanak Sagar reservoir

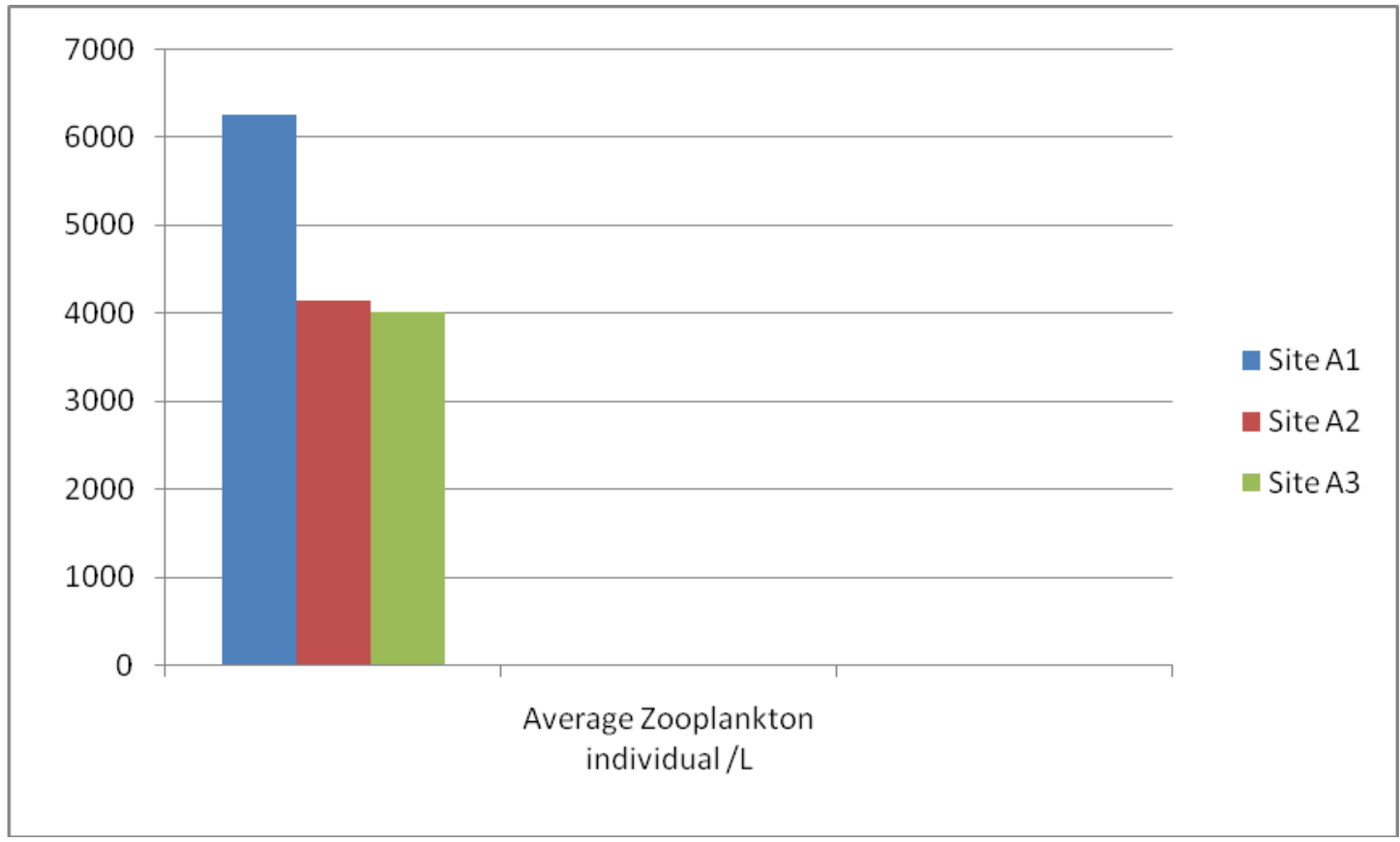

The relative abundance of the zooplankton varied from 35 percent to 40 percent for Rotifera; from 31.5 percent to 36 percent for Copepoda; from 24 percent to 32 percent for Cladocera; from 0 percent to 2 percent for Ostracoda and from 0 percent to 2 percent for Diptera at site A1. At site A2 zooplankton group variation was from 32 percent to 40 percent among Rotifera; from 33 percent to 39 percent for Copepoda; from 23.5 percent to 30 percent for Cladocera; from 0 percent to 1.5 percent for Ostracoda and from 0 percent to 3 percent Diptera. At site A3 they varied from 31 percent to 39 percent for Rotifera; from 27 percent to 37 percent for Copepoda; from 26 percent to 34.5 percent for Cladocera; from 0 percent to 2 percent for Ostracoda and from 0 percent to 2 percent Diptera.

Rotifera was the most abundant and dominant group at station A1 with average percent of 35.37 followed by 32.25 percent of Copepods; 31.06 percent Cladocera; 0.56 percent Diptera and 0.5 percent Ostracoda. At station A2 35.81 percent of population was dominated by copepoda followed by 35.68 percent Rotifera; 26.62 percent Cladocera; 1.43 percent was Diptera and 0.62 percent Ostracoda. At Station A3 zooplankton population was dominated by rotifers $(35.60$ percent) followed by copepod (32.25 percent); Cladocera (31.06 percent); 0.56 percent Diptera and 0.5 percent Ostracoda. The abundance and distribution of zooplankton is guided by a variety of ecological factors. The physio-chemical parameters such as temperature, light, $\mathrm{pH}$ and endemic constituents and the interrelationship with other organisms play an important role in determining the nature and pattern of fluctuation of population densities of zooplankton in an environmental unit. The importance of these factors has been stressed by several workers including Arora (2003), John et al., (1980), Rajendra (1992), Kumar and Datta (1994), Kodarkar (1992) and Desilva (2002). However these parameters are extremely variable from place to place and from time to time. These parameters also interact with each other in a variety of ways. In such conditions it is rather difficult to draw 
specific conclusions about the individual effects of these parameters on population densities of zooplankton. But it can be expressed in general that the fluctuating patterns of physico-chemical conditions of water affects the distribution of zooplankton.

Maximum density of zooplankton occurred at site A1 (18200 individuals $\left.\mathrm{L}^{-1}\right)$ during February whereas minimum population (1850 individuals $\mathrm{L}^{-1}$ ) was recorded during August at site A2. Generally the density of zooplankton was lower at site A2 in all months as compared to site A1 and A3. The average density of zooplankton at the three selected sites of reservoir i.e. A1, A2 and A3 were 6250 individuals $\mathrm{L}^{-1}, 4125$ individuals $\mathrm{L}^{-}$ ${ }^{1}$ and 4000 individuals $\mathrm{L}^{-1}$ respectively. The highest value of zooplankton were found in the month of February and the values were 18200 individuals $\mathrm{L}^{-1}, 11200$ individuals $\mathrm{L}^{-1}$ and 12800 individuals $\mathrm{L}^{-1}$ at the sites $\mathrm{A} 1, \mathrm{~A} 2$ and $\mathrm{A} 3$, respectively. The lowest density of zooplankton was observed in the month of August and the values were 3000 individuals $\mathrm{L}^{-1}, 1850$ individuals $\mathrm{L}^{-1}$ and 2400 individuals $\mathrm{L}^{-1}$ at the sites $\mathrm{A} 1, \mathrm{~A} 2$ and $\mathrm{A} 3$, respectively. The density of zooplankton was lowest at site A2 in all the months as compared to site A1 and A3 because of little continuous flow through irrigation canal as outlet.

According to Shapiro et al., (1975) the trophic cascade theory predicts that increased planktivorous fish biomass reduces the biomass of zooplankton and consequently increases phytoplankton biomass. Nanak Sagar reservoir is dominated by planktivorous fishes. Meerhoff et al., (2007) stated that tropical and subtropical systems, fish typically maintain a quasi-permanent sizeselective predation pressure on zooplankton, even in the presence of submerged macrophytes, that influence to lead a reduced abundance of large bodied herbivorous zooplankton.
Various indices such as Shannon-Wiener diversity index $(\mathrm{H})$ and Simpson index of diversity (D), were used to analyze species diversity. The analyzed data revealed the maximum species diversity in terms of Shannon-Wiener Index $(\mathrm{H}=3.32)$ at site A2 whereas minimum value of this was recorded at station $\mathrm{A} 1$ and $\mathrm{A} 3$ with $\mathrm{H}=3.14$ and 3.12 respectively. Higher the value of $\mathrm{H}$, higher is the diversity of the ecosystem. The species diversity approach is generally a more reliable measure of biodiversity than other indices such as species richness. The maximum zooplankton diversity in terms of Simpson index of diversity (D) was recorded at site A2 i.e. $(D=0.3097)$ and minimum species diversity were recorded at site A1 and A2 with values of $\mathrm{D}=0.3210$ and 0.3210 respectively. A lower value of $\mathrm{D}$ indicates higher biodiversity.

In our study the probability that two randomly selected individuals will belong to the same species at the site $\mathrm{A} 1$ and $\mathrm{A} 3$ community $(\mathrm{D}=$ $0.3210)$ is higher than the site $A 2(\mathrm{D}=0.3097)$ indicating lower biodiversity at site A1 and A3 as compared A2. According to Xie et al., (1996) the species diversities of copepods and rotifers responded differently to water nutrient levels; when the levels changed from nutrientmoderate to nutrient-rich, the species diversity decreases (i.e., nutrient enrichment decreased zooplankton diversity). Because contamination-resistant species in nutrientrich water can become dominant and the growth of other species is inhibited, which can decrease diversity. Among the zooplankton rotifers respond more quickly to the environmental changes and used as indicator for a change in water quality (Gannon and Stemberger, 1978). ShannonWeaner Index is a combination of the number of species and the evenness of distribution of individuals among taxa. It may function as a sensitive indicator for pollution (Klemm et al., 1990). 
The results indicate that distribution and diversity of zooplankton is depending on the physico-chemical parameters prevailing in the environment. Hence measures should be taken to minimize the pollution by minimizing or preventing boating and other human activities. It is understood that the Nanak Sagar reservoir is very good for natural pisciculture (fin-fish and shell-fish) practices. In addition, the data generated from this investigation are being useful to the decision maker for the effective conservation and sustainable utilization of this water body.

\section{Acknowledgement}

Authors are grateful to Dr. Malobica Das Trakroo, Dr. A.P. Sharma and Dr. Ashutosh Mishra, Professors Aquatic Environment Management, for providing guidance and facilities to purse the present study at College of Fisheries of G. B. Pant University of Agriculture and Technology, Pantnagar.

\section{References}

APHA, 2012. Standard methods for the examination of the water and waste water. 22th edition. American Public Health Association, Washington Aquaculture Engineering. p. 19.

Arora, J. and Mehra, N., 2003. Seasonal dynamics of Rotifers to physical and chemical conditions of river Yamuna (Delhi), India, Hydrobiologia, 491(1):101-109.

Deborah and Robert., 2009. Patterns and causes of species richness: a general simulation model for macroecology. Ecology Letters, 12(9): 873-886.

Desilva., 2002. Distributional patterns of the euphausiid community in Bahía de $\mathrm{La}$ Paz, BCS, México. Contributions to the study of the East Pacific crustaceans. Instituto de Ciencias del Mary
Limnología, Universidad Nacional Autónoma de México. México, $D F$, pp. 109-125.

Dipankar Ghosh, and Biswas J.K., 2014. Zooplankton Diversity Indices: Assessment of an Ox-Bow Lake Ecosystem for Sustainable Management in West Bengal. International Journal of Advanced Biotechnology and Research, 6(1): 37-43.

Edmonson T. W., and Ward B.H., 1959. Freshwater Biology. New York, Wiley. $1248 \mathrm{pp}$.

Gannon, J.E. and Stemberger, R.S., 1978. Zooplankton (especially crustaceans and rotifers) as indicators of water quality. Transactions of the American Microscopical Society, 97(1): 16-35.

Hare, L. and Carter, J.C., 1987. Zooplankton populations and the diets of three Chaoborus species (Diptera, Chaoboridae) in a tropical lake. Freshwater Biology, 17(2): 275 290.

Irvine, K., 1997. Food selectivity and diel vertical distribution of Chaoborus edulis (Diptera, Chaoboridae) in Lake Malawi. Freshwater Biology, 37(3): 605-620.

Jalilzadeh, A.K., Yamakanamardi, S.M. and Altaff, K., 2008. Abundance of zooplankton in three contrasting lakes of Mysore city, Karnataka state, India, 464-469.

John, T. W. Snell, R. Guo., 1980. The effect of interference competition in Asplanchna brightwelli on its predation capacity, Journal of Plankton Research, 36(5): 1391-1399.

Kanagasabhapati, V. and Rajan, M. K. 2010. A Preliminary survey of plankton in Irrukkangudi reservoir, Virudhnagar District, Journal of Phytology, 2(3): 63 72.

Kedar, G.K., Patil, G.P. and Yeole, S.M., 2008. Effect of physicochemical factors 
on the seasonal abundance of zooplankton population in Rishi Lake. In Proceeding of Taal: the 12th world lake conference, pp. 88-91.

Klemm, D.J., Lewis, P.A. Fulk, F., Lazorchak, J.M. 1990. Macroinvertebrate field and laboratory methods for evaluating the biological integrity of surface waters, U.S. Environmental Protection Agency, Environmental Monitoring and Support Laboratory, Cincinnati, Ohio, p. 99.

Kodarkar, MS., 1992. Methodology for water analysis, physico-chemical, biological and microbiological. Hyderabad, Indian Association of Aquatic Biologists (I.A.A.B.) Publ.75: 57- 63.

Kudari, V.A., Kadadevaru, G.G. and Kanamadi, R.D., 2005. Zooplankton composition in some ponds of Haveri district, Karnataka. Zoo's print Journal, 20(12): 2094-2099.

Kumar, S. and Datta, S.P.S., 1994. Zooplankton Diversity of Wan Reservoir, Nagpur (MS) India. Trends Research in Science and Technology, 2(1): 39-48.

Madin, L.P., Horgan, E.F. and Steinberg, D.K., 2001. Zooplankton at the Bermuda Atlantic Time-series Study (BATS) station: diel, seasonal and interannual variation in biomass, 1994 1998. Deep Sea Research Part II: Topical Studies

Oceanography, 48(8): 2063-2082.

Magadza, C.D., 1994. Evaluation of eutrophication control in Lake Chivero, Zimbabwe, by multivariate analysis of zooplankton. Hydrobiologia, 272(1): 277-292.

Martin Gross., Gitter, F., and Piller, W.E., 2015. Sub-decadal resolution in sediments of Late Miocene Lake Pannon reveals speciation of Cyprideis (Crustacea, Ostracoda). PloS one, 10(4):10960.
Meerhoff, M., Iglesias, C., De Mello, F.T., Clemente, J.M., Jensen, E., Lauridsen, T.L. and Jeppesen, E., 2007. Effects of habitat complexity on community structure and predator avoidance behaviour of littoral zooplankton in temperate versus subtropical shallow lakes. Freshwater Biology, 52(6): 10091021.

Naz, S. and Najia, S., 2008. Study on the zooplankton of Sona Dighi in Rajshahi, Bangladesh. University Journal of Zoology, Rajshahi University, 27(14): 7-11.

Needham J.G. and Needham P.R., 1962. A guide to study freshwater biology. Holden Bay, San Fransisco, U.S.A. 83pp.

Neves, I.F., Rocha, O., Roche, K.F. and Pinto, A.A., 2003. Zooplankton community structure of two marginal lakes of the river Cuiabá (Mato Grosso, Brazil) with analysis of Rotifera and Cladocera diversity. Brazilian Journal of Biology, 63(2): 329-343.

Pawar, S.K. and Pulle, J.S., 2005. Qualitative and Quantitative Study of Zooplankton in Pethwadaj Dam, Nanded, District (Maharashtra), India. Journal of Aquatic Biology, 20(2): 53-57.

Pennak R.W., 1978. Freshwater Invertebrates of United State. $2^{\text {nd }}$ edition John Wiley \& Sons, New York. 822pp.

Pourriot and Meybeck., 1995. Seasonal succession of diatoms and Chlorophyceae in the drainage network of the Seine River: observation and modeling. Limnology and Oceanography, 40(4): 750-765.

Rajendra, M.C., 1992. Copepoda species. The freshwater zooplankton of India, SK Battish. 447.

Saint-Jean, L., 1983. The zooplankton. In Lake Chad, Springer 22(2):199-232.

Segers, H., 2003. Global diversity of rotifers (Rotifera) in 
freshwater. Hydrobiologia, 595(1): 4959.

Shapiro, J., Lamarra, V.A. and Lynch, M., 1975. Biomanipulation: an ecosystem approach to lake restoration. 411pp.

Somani, V. and Pejawar, M., 2004. Crustacean zooplankton population of the lake of Masunda, Thane, Maharashtra. J. Aqua. Biol, 19(1): 5756.

Sukand, B.N. and Patil, H.S. 2004. Water quality assessment of Fort lake of Belgaum (Karnataka) with special reference to zooplankton. Journel of Environmental Biology, 25(1): 99- 102.

Suresh Kumar, R., and Raghunathan, M.B. 1999. Cladocera (Crustacea) of
Tamilnadu checklist and bibliography. Zoos Print J, 17(12): 959961.

Tonapi T.G., 1980. Freshwater water animal of India: an ecological approach. Oxford and IBH. 856pp.

Wetzel, R.G., 2001. Limnology: lake and river ecosystems. Gulf Professional Publishing. 522pp.

Xie, P. and Yang, Y., 1996. Long-term changes of Copepoda community in a subtropical Chinese lake stocked densely with planktivorous filterfeeding silver and bighead carp. Journal of Plankton Research, 22(9): 17571778.

\section{How to cite this article:}

Sumit Kumar, Malobica Das Trakroo, Kusumlata Goswami and Hema Tewari. 2018. Observations on Zooplankton Community of Nanak Sagar Reservoir, Uttarakhand, India. Int.J.Curr.Microbiol.App.Sci. 7(10): 339-349. doi: https://doi.org/10.20546/ijcmas.2018.710.036 